\title{
Analisis Kemampuan Pemahaman Konsep Matematis dan Kemampuan Pemecahan Masalah Matematis Siswa SMP pada Materi Sistem Persamaan Linear Dua Variabel (SPLDV)
}

\author{
Suraji $^{1}$, Maimunah ${ }^{2}$, Sehatta Saragih ${ }^{3}$ \\ ${ }^{1}$ Mahasiswa Program Studi Magister Pendidikan Matematika, Universitas Riau \\ ${ }^{2,3}$ Dosen Program Studi Magister Pendidikan Matematika, Universitas Riau \\ e-mail: suraji6276@grad.unri.ac.id
}

\begin{abstract}
ABSTRAK. Penelitian ini bertujuan untuk mengetahui kemampuan pemahaman konsep matematis dan kemampuan pemecahan masalah matematis siswa pada materi Sistem Persamaan Linear Dua Variabel (SPLDV). Penelitian ini dilaksanakan pada semester genap tahun ajaran 2017/2018 di Pekanbaru. Populasi pada penelitian ini adalah seluruh siswa kelas VIII SMP IT Dar Al-Ma'arif Pekanbaru dengan jumlah sampel sebanyak 28 orang siswa. Instrumen penelitian yang digunakan berupa soal tes kemampuan pemahaman konsep dan kemampuan pemecahan masalah matematis. Metode penelitian yang digunakan adalah desain penelitian kualitatif. Data dianalisis dengan menggunakan reduksi data, penyajian data, dan penarikan kesimpulan. Berdasarkan hasil penelitian dapat disimpulkan bahwasanya kemampuan pemahaman konsep matematis dan kemampuan pemecahan masalah matematis siswa SMP pada materi SPLDV masih rendah terutama dalam mengaplikasikan dalam kehidupan sehari-hari.
\end{abstract}

Keywords : pemahaman konsep, pemecahan masalah, materi SPLDV

\section{PENDAHULUAN}

Pendidikan merupakan usaha manusia untuk mengubah dan membina kepribadian berlandaskan dengan nilai-nilai baik di dalam masyarakat maupun kebudayaan melalui proses pendidikan. Dalam hal ini, pendidikan sangat erat kaitannya dengan pembelajaran. Dimana belajar pada dasarnya merupakan kunci yang paling vital dalam setiap usaha pendidikan.

Melalui pendidikan manusia memperoleh ilmu pendidikan yang dapat dijadikan tuntunan dalam kehidupan dan dengan pendidikan orang menjadi maju serta mampu bersaing dengan negara lain dalam segala bidang. Kamarullah (2017) menegaskan siswa dituntut sesuai kuruikulum dengan tujuan yang lebih komprehensif, yakni : (1) memahami konsep matematika, menjelaskan keterkaitan antarkonsep dan mengaplikasikan konsep atau algoritma, secara luwes, akurat, efisien, dan tepat, dalam pemecahan masalah; (2) menggunakan penalaran pada pola dan sifat, melakukan manipulasi matematika dalam membuat generalisasi, menyusun bukti, atau menjelaskan gagasan dan pernyataan matematika; (3) memecahkan masalah yang meliputi kemampuan memahami masalah, merancang model matematika, menyelesaikan model dan menafsirkan solusi yang diperoleh; (4) mengomunikasikan gagasan dengan simbol, tabel, diagram, atau media lain untuk memperjelas keadaan atau masalah; (5) memiliki sikap menghargai kegunaan matematika dalam kehidupan, yaitu memiliki rasa ingin tahu, perhatian, dan minat dalam mempelajari matematika, serta sikap ulet dan percaya diri dalam pemecahan masalah. Matematika merupakan salah satu bagian yang penting dalam bidang ilmu pengetahuan. Apabila dilihat dari sudut pengklasifikasian bidang ilmu pengetahuan, matematika termasuk ke dalam ilmu-ilmu eksakta yang lebih banyak memerlukan pemahaman dari pada hapalan. 
Untuk dapat memahami suatu pokok bahasan dalam matematika, siswa diharapkan mampu memiliki kemampuan matematis yang berguna untuk menghadapi tantangan global. Kemampuan tersebut diantaranya kemampuan pemahaman konsep dan pemecahan masalah matematis merupakan kemampuan yang sangat diperlukan oleh setiap orang dalam menyelesaikan permasalahan kehidupan serta menghadapi tantangan global saat ini.

Kemampuan pemahaman konsep dan pemecahan masalah matematis merupakan dua kemampuan yang telah dinyatakan berdasarkan standar isi (SI) mata pelajaran matematika untuk satuan pendidikan menurut Nela (2014), dijelaskan bahwa tujuan pembelajaran matematika di sekolah agar siswa memiliki kemampuan sebagai berikut.

1. Memahami konsep matematika, menjelaskan keterkaitan antar konsep dan mengaplikasikan konsep atau algoritma secara luwes, akurat, efesien dan tepat dalam pemecahan masalah.

2. Menggunakan penalaran pada pola dan sifat, melakukan manipulasi matematika dalam membuat generalisasi, menyusun bukti atau menjelaskan gagasan dan pernyataan matematika.

3. Memecahkan masalah yang meliputi kemampuan memahami masalah, merancang model matematika, menyelesaikan model dan menafsirkan solusi yang diperoleh.

4. Mengkomunikasikan gagasan dengan simbol, tabel, diagram, atau media lain untuk memperjelas keadaan atau masalah.

5. Memiliki sikap menghargai kegunaan matematika dalam kehidupan, yaitu memiliki rasa ingin, perhatian, dan minat dalam mempelajari matematika, serta sikap ulet dan percaya diri dalam pemecahan masalah.

Salah satu organisasi pendidikan matematika internasional melalui National Council of Teacher of Mathematics (NCTM) dalam Rosliana juga menyatakan bahwa ada beberapa aspek yang termasuk dalam kemampuan berpikir matematis di antaranya adalah kemampuan pemahaman, pemecahan masalah matematis, komunikasi matematis, penalaran dan pembuktian matematis, koneksi matematis dan representasi matematis. Dari tujuan tersebut dalam mempelajari matematika siswa dituntut untuk memiliki kemampuan pemahaman konsep dan pemecahan masalah matematis dalam menyelesaikan masalah matematika.

Berdasarkan uraian di atas, maka kemampuan pemahaman konsep dan pemecahan masalah matematis merupakan dua kemampuan yang sangat penting untuk dikembangkan. Susanto di dalam Fadhila (2014) menyatakan kemampuan pemahaman konsep merupakan kemampuan siswa untuk dapat mengerti konsep yang diajarkan guru. Lebih lanjutnya menurut Fadhila kemampuan siswa dalam menjelaskan konsep yang telah dipelajari dengan menggunakan kata-kata sendiri. Ana (2010) mengatakan kemampuan pemahaman matematis ini adalah kemampuan pemahaman menurut Skemp yaitu (1) pemahaman instrumental dimana siswa mampu menghapal rumus/prinsip, dapat menerapkan rumus dalam perhitungan sederhana dan mengerjakan pehitungan secara algoritmik; (2) pemahaman relasional, dimana siswa mampu mengaitkan sesuatu dengan hal lainnya secara benar serta menyadari prosesnya. Berdasarkan uraian diatas, peneliti dapat menyimpulkan definisi pemahaman konsep adalah kemampuan yang dimiliki seseorang untuk mengemukakan kembali ilmu yang diperolehnya baik dalam bentuk ucapan maupun tulisan kepada orang sehingga orang lain tersebut benar-benar mengerti apa yang disampaikan.

Uraian di atas mengindikasikan bahwa betapa pentingnya pemilihan kemampuan pemahaman konsep oleh siswa dalam pembelajaran di sekolah. Indikasi rendahnya kemampuan pemahaman konsep ini ditandai oleh beberapa gejala bahwa sebagian siswa MTs Darul Hikmah Pekanbaru belum bisa memilih prosedur atau operasi yang sesuai dalam menyelesaikan soal, siswa belum bisa mengaplikasikan konsep yang telah diajarkan jika diberikan soal cerita, siswa mengalami kesulitan dalam menyelesaikan soal yang modelnya sedikit berbeda dari contoh dan siswa kurang paham dalam menentukan hal-hal yang diketahui pada soal cerita. Fakta lain dari hasil penulisan yang dilakukan oleh Aan Hendrayana (2017) mengatakan bahwa kemampuan pemahaman konsep matematis siswa SMP masih belum seperti yang diharapkan, siswa masih bingung jika dihadapkan dengan persoalan luas jajargenjang kemudian mereka tidahafal rumus mencari luasnya. Ali Ardhi (2017) menyimpulkan bahwa kemampuan pemahaman konsep siswa SMP juga masih belum 
memuaskan. Sudirta dalam Artana (2014) mengidentifikasi faktor utama penyebab rendahnyakemampuan pemecahan masalah matematika siswa, yaitu pembelajaran yang dilaksanakan selama ini belum mampu mengembangkan kemampuan mengkomunikasikan ide-ide matematika siswa secara tepat, mengembangkan kemampuan pemahaman konsep matematika siswa dan mengembangkan kemampuan pemecahan masalah matematika siswa.

Selanjutnya menurut Suryadi dkk. dalam surveinya tentang "Current situation on mathematics and science education in Bandung" yang disponsori oleh JICA, antara lain mengemukakan bahwa pemecahan masalah matematika merupakan salah satu kegiatan matematika yang dianggap penting baik oleh para guru maupun siswa di semua tingkatan sekolah mulai dari sekolah dasar sampai sekolah atas. Akan tetapi, hal tersebut masih dianggap sebagai bagian yang paling sulit dalam matematika baik bagi siswa dalam mempelajarinya maupun bagi guru dalam mengajarkannya. Ana (2010) juga menegaskan kemampuan pemecahan masalah matematik adalah kemampuan siswa dalam menyelesaikan soal matematik berdasarkan langkah-langkah penyelesaian masalah matematik menurut Polya, yaitu : (1) memahami persoalan, (2) membuat rencana penyelesaian, (3) menjalankan rencana, (4) melihat kembali apa yang telah dilakukan. Pemecahan masalah tidak sekedar sebagai bentuk kemampuan menerapkan aturan-aturan yang telah dikuasai melalui kegiatan-kegiatan belajar terdahulu, melainkan lebih dari itu, merupakan proses untuk mendapatkan seperangkat aturan pada tingkat yang lebih tinggi.

Dari beberapa hasil penelitian terdahulu juga mengindikasikan rendahnya kemampuan pemecahan masalah matematis siswa. Hasil penelitian yang saya lakukan di tingkat dasar, kemampuan pemecahan masalah peserta didik cukup rendah dan dapat difasilitasi dengan bahan ajar, begitu juga penelitian yang dilakukan oleh Susanti (2017) dan Umy Hasanatul dkk (2017) bahwa kemampuan pemecahan masalah matematis siswa, khususnya siswa SMP/MTs masih rendah. Laporan TIMMS tahun 1999 (Herman, 2006) juga menunjukkan kemampuan siswa SMP/MTs relatif lebih baik dalam menyelesaikan soal-soal tentang fakta dan prosedur, akan tetapi sangat lemah dalam menyelesaikan soal-soal tidak rutin yang berkaitan dengan jastifikasi atau pembuktian, pemecahan masalah yang memerlukan penalaran matematika, menemukan generalisasi atau konjektur, dan menemukan hubungan antara data-data atau fakta yang diberikan. Sedangkan gejala rendahnya kemampuan pemecahan masalah matematis di SMP/MTs Pekanbaru menunjukkan bahwa siswa masih mengalami kesulitan dalam menyelesaikan soal pemecahan masalah. Hal ini terlihat ketika guru memberikan latihan soal dalam bentuk soal cerita pada materi Sistem Persamaan Linear Dua Variabel (SPLDV). Siswa mengalami kesulitan ketika mengerjakan soal yang berbeda dari contoh soal yang diberikan guru, sebagian besar siswa hanya menghafalkan rumus tanpa memahami proses mendapatkan rumus tersebut, mereka sulit menyusun rencana untuk melengkapi data-data yang dibutuhkan menggunakan informasi yang diketahui. Selain itu, jika diberikan soal cerita dengan data-data pengecoh, sebagian besar siswa terkecoh dan menganggap bahwa semua data yang diberikan pada soal harus digunakan untuk menemukan solusi.

Berdasarkan uraian diatas, peneliti ingin menganalisis kemampuan pemahaman konsep dan pemecahan masalah matematis siswa pada materi Sistem Persamaan Linear Dua Variabel (SPLDV). Ana (2010) menyimpulkan bahwa terdapat hubungan antara kemampuan pemahaman dan pemecahan masalah matematik siswa SMP. Sehingga karena sudah ada hubungan ini, peneliti dapat menganalis kedua kemampuan tersebut pada materi Sistem Persamaan Linear Dua Variabel (SPLDV). Rumusan masalah dalam penelitian ini adalah bagaimana kemampuan pemahaman konsep dan pemecahan masalah matematis siswa SMP dalam menyelesaikan masalah Sistem Persamaan Linear Dua Variabel (SPLDV). Dipilihnya materi SPLDV dikarenakan pada materi tersebut, jika disajikan dalam bentuk soal cerita, sebagian besar siswa belum bisa mengerjakan. 


\section{METODE PENELITIAN}

Penelitian ini merupakan penelitian kualitatif. Penelitian ini bertujuan mendeskripsikan kemampuan pemahaman konsep dan pemecahan masalah matematis siswa pada Sistem Persamaan Linear Dua Variabel (SPLDV) tanpa diberikan perlakuan apapun sebelumnya. Penelitian ini dilakukan pada semester genap pada salah satu SMP di Pekanbaru. Populasi pada penelitian ini adalah seluruh peserta didik kelas VIII SMP IT Dar Al-Ma'arif Pekanbaru pada tahun ajaran 2017/2018. Subjek penelitian ini adalah sebanyak 28 orang siswa. Instrumen penelitian yang digunakan adalah berupa instrumen soal tes pemahaman konsep matematis dan kemampuan pemecahan masalah matematis dan rubrik penilaian. Adapun data yang digunakan diperoleh melalui kegiatan tes, yaitu dengan melakukan tes yang terdiri atas tiga soal kemampuan pemahaman konsep dan tiga soal kemampuan pemecahan masalah matematis, dengan rincian indikator yang digunakan pada penelitian ini untuk kedua kemampuan sebagai berikut:

1. Indikator kemampuan pemahaman konsep matematis (Berdasarkan Wardani dalam Fadhila (2014): Dalam penelitian ini kemampuan pemahaman konsep matematis akan diukur dengan menggunakan indikator diantaranya yaitu:

a. Menyatakan ulang sebuah konsep

b. Mengklasifikasikan objek-objek menurut sifat-sifat tertentu sesuai dengan konsepnya

c. Memberi contoh dan bukan contoh dari suatu konsep

d. Menyajikan konsep dalam berbagai bentuk representasi matematis

e. Mengembangkan syarat perlu atau syarat cukup suatu konsep

f. Menggunakan, memanfaatkan, dan memilih prosedur atau operasi tertentu dan,

g. Mengaplikasikan konsep

Dari indikator di atas, peneliti menggabungkan beberapa indikator sehingga menjadi tiga item indikator, yaitu :

A : menyatakan ulang sebuah konsep dan mengklasifikasikan objek sesuai dengan konsepnya

B : menyajikan konsep dalam berbagai bentuk representasi matematis

C : menggunakan, memanfaatkan, dan memilih prosedur atau operasi tertentu dan mengaplikasikan konsep.

2. Indikator kemampuan pemecahan masalah matematis (Berdasarkan Polya dalam Sumarmo (2013): Dalam penelitian ini kemampuan pemecahan masalah matematis akan diukur dengan menggunakan indikator diantaranya yaitu:

a. Mengidentifikasi kecukupan data untuk pemecahan masalah.

b. Memilih dan menerapkan strategi untuk menyelesaikan masalah matematika dan atau di luar matematika.

c. Menjelaskan dan menginterpretasikan hasil.

Dari indikator di atas, peneliti menggabungkan beberapa indikator sehingga menjadi dua item indikator, yaitu :

A : memiilih dan menerapkan strategi untuk menyelesaikan masalah matematika dan atau di luar matematika

B : menjelaskan dan menginterpretasikan hasil

Instrumen penelitian berupa soal-soal yang disusun berdasarkan indikator pemahaman konsep dan kemampuan pemecahan masalah matematis, yaitu soal kontektual yang mengambil pokok bahasan sistem persamaan linear dua variabel. Dalam menyusun soal - soal tersebut peneliti bekerja sama dengan guru mata pelajaran matematika SMP IT Dar Al-Ma'arif Pekanbaru setelah dikonsultasikan dengan tim validator. Validitas item berkenaan dengan kesanggupan alat penelitian dalam mengukur item soal yang seharusnya, artinya tes tersebut harus mampu mengungkapkan isi suatu konsep atau variabel yang hendak diukur, setelah peneliti melakukan analisis terhadap soal tes yang berupa soal-soal pemahaman konsep dan pemecahan masalah. Dengan demikian dapat disimpulkan bahwa soal tes telah memenuhi validitas item karena soal tes tersebut sudah sesuai 
dengan kurikulum (materi dan ujian) dan telah memenuhi kisi-kisi dalam materi pelajaran di sekolah tersebut.

Teknik analisis data yang digunakan dalam penelitian ini adalah analisis data kualitatif meliputi: (1) reduksi data adalah proses pemilihan hal-hal pokok, penyederhanaan, dan memfokuskan pada hal-hal yang penting. Dalam hal ini peneliti mencatat hasil wawancara serta mengumpulkan data tes dan dokumentasi dari informan yang berkaitan dengan pemahaman konsep dan pemecahan masalah matematis siswa dalam menyelesaikan soal, (2) penyajian data berupa informasi dalam bentuk teks naratif yang disusun, diringkas, dan diatur agar mudah dipahami dan merencanakan kerja penelitian selanjutnya. Peneliti menyusun data yang relevan sehingga menjadi informasi yang dapat disimpulkan dan memiliki makna tertentu, (3) penarikan kesimpulan adalah tahap analisis data yang telah disajikan dalam bentuk tabel. Untuk mengetahui persentase kesalahan-kesalahan setiap indikator pemahaman konsep matematika dalam menyelesaikan dan memecahkan masalah dalam soal kontektual pokok bahasan SPLDV digunakan rumus sebagai berikut:

\section{Keterangan:}

$$
P=\frac{\text { Total } \sum s}{\text { Total } \sum s+\text { Total } \sum b} \times 100 \%
$$

$\mathrm{P}=$ Persentasi kesalahan yang dialami siswa

$\Sigma s=$ Jumlah soal yang salah (mengalami kesalahan dalam memahami konsep dan memecahkan masalah matematis) dari total semua soal

$\Sigma b=$ Jumlah soal yang benar (tidak mengalami kesalahan dalam memahami konsep dan memecahkan masalah matematis) dari total semua soal

Untuk mengetahui tinggi rendahnya persentase pemahaman konsep dan pemecahan masalah matematis siswa maka peneliti menggunakan acuan sebagai berikut:

Tabel 1. Persentase kemampuan Siswa

\begin{tabular}{cc}
\hline Persentase (\%) & Kriteria \\
\hline $0 \leq \mathrm{P}<20$ & Sangat Rendah \\
\hline $20 \leq \mathrm{P}<40$ & Rendah \\
\hline $40 \leq \mathrm{P}<60$ & Sedang \\
\hline $60 \leq \mathrm{P}<80$ & Tinggi \\
\hline $80 \leq \mathrm{P}<100$ & Sangat Tinggi \\
\hline Arikunto (2009) &
\end{tabular}

Ket: $\mathrm{P}$ adalah persentase kesalahan siswa pada pemahaman konsep dan pemecahan masalah

\section{HASIL DAN PEMBAHASAN \\ HASIL}

Penelitian ini dilakukan pada kelas VIII SMP IT Dar Al-Ma'arif yang berjumlah 28 orang siswa dengan memberikan 6 soal tes diantaranya 3 soal kemampuan pemahaman konsep dan 3 soal kemampuan pemecahan masalah matematis siswa. Setelah itu dilakukan wawancara dengan siswa mengenai soal yang telah mereka kerjakan tadi, selanjutnya peneliti melakukan wawancara terhadap guru matematika kelas VIII SMP IT Dar Al-Ma'arif.

Dari hasil pengerjaan soal yang telah diselesaikan siswa maka diperoleh data kemampuan pemahaman konsep dan pemecahan masalah matematis siswa dalam menyelesaikan soal SPLDV ditinjau dari indikator kemampuan pemahaman konsep dan pemecahan masalah matematis yang telah dijelaskan. Untuk lebih jelasnya diawali dengan analisis jawaban siswa.

Tabel 2. Kesalahan dalam setiap indikator dan jumlah kesalahan dalam setiap indikator yang dialami siswa 


\begin{tabular}{|c|c|c|c|c|c|c|}
\hline \multirow[t]{2}{*}{ Kemampuan } & \multirow[t]{2}{*}{ Indikator } & \multirow[t]{2}{*}{ Jumlah Item } & \multicolumn{3}{|c|}{ Nomer Item Soal } & \multirow[b]{2}{*}{ Total } \\
\hline & & & 1 & 2 & 3 & \\
\hline \multirow{6}{*}{$\begin{array}{l}\text { Pemahaman } \\
\text { Konsep }\end{array}$} & \multirow[t]{2}{*}{ A } & $\sum \mathrm{B}$ & 28 & 28 & 26 & 82 \\
\hline & & $\sum \mathrm{S}$ & 0 & 0 & 2 & 2 \\
\hline & \multirow{2}{*}{ B } & $\sum \mathrm{B}$ & 26 & 27 & 27 & 80 \\
\hline & & $\sum \mathrm{S}$ & 2 & 1 & 1 & 4 \\
\hline & \multirow{2}{*}{$\mathrm{C}$} & $\sum \mathrm{B}$ & 27 & 28 & 28 & 83 \\
\hline & & $\sum \mathrm{S}$ & 1 & 0 & 0 & 1 \\
\hline \multirow{4}{*}{$\begin{array}{c}\text { Pemecahan } \\
\text { Masalah }\end{array}$} & \multirow{2}{*}{ A } & $\sum \mathrm{B}$ & 26 & 27 & 25 & 78 \\
\hline & & $\sum \mathrm{S}$ & 2 & 1 & 3 & 6 \\
\hline & \multirow{2}{*}{ B } & $\sum \mathrm{B}$ & 27 & 25 & 27 & 79 \\
\hline & & $\sum \mathrm{S}$ & 1 & 3 & 1 & 5 \\
\hline
\end{tabular}

Berdasarkan Tabel 2 maka diperoleh persentase kesalahan tiap aspek indikator pemahaman konsep matematis yaitu: pada indikator $\mathrm{A}$ adalah kesalahan dalam menyatakan ulang sebuah konsep dan mengklasifikasikan objek sesuai dengan konsepnya yaitu sebesar 2,38\% maka tergolong dalam kriteria sangat rendah, pada indikator $\mathrm{B}$ adalah kesalahan menyaijkan konsep dalam berbagai bentuk representasi matematis yaitu sebesar 4,76\% maka tergolong dalam kriteria sangat rendah, dan pada indikator $\mathrm{C}$ adalah kesalahan dalam menggunakan, memanfaatkan, dan memilih prosedur atau operasi tertentu dan mengaplikasikan konsep yaitu sebesar 1,19\% maka tergolong dalam kriteria sangat rendah.

Pada indikator A dan B ini sebagian besar siswa mampu dengan baik dalam mengklasifikasi dan menyajikan konsep dalam berbagai bentuk representasi matematis, hanya saja ada beberapa orang siswa yang mengalami kekeliruan. Dan berdasarkan wawancara yang dilakukan kepada siswa, siswa keliru dalam memahami soal sehingga soal tersebut tidak dikerjakan. Hal tersebut menunjukkan bahwa siswa cenderung bingung dalam mengkomunikasikan pernyataan yang diketahui ke dalam model matematika. Namun pada indikator $C$ kesalahan terjadi karena siswa bingung menggunakan dan mengaplikasikan konsep yang mana seharusnya digunakan. Ini disebabkan karena siswa tidak memahami soal dengan baik.

Sedangkan persentase kesalahan tiap aspek indikator pemecahan masalah matematis yaitu: pada indikator A adalah kesalahan dalam memiilih dan menerapkan strategi untuk menyelesaikan masalah matematika dan atau di luar matematika yaitu sebesar 7,14\% maka tergolong dalam kriteria sangat rendah, pada indikator B adalah kesalahan menjelaskan dan menginterpretasikan hasil yaitu sebesar 5,95\% maka tergolong dalam kriteria sangat rendah.

Pada indikator A dan B pemecahan masalah kesalahan siswa cenderung kepada kesalahan dalam melakukan perhitungan, sehingga penyelesaian menjadi tidak tepat. Berdasarkan hasil wawancara kepada siswa, sebenarnya soal SPLDV ini sangat mudah, karena materi SPLDV sudah pernah didapat sebelumnya, saat diajarkan pak Muliadi pada semester satu dulu siswa sudah menguasai materi SPLDV ini. Ini menunjukkan bahwa siswa masih ada beberapa siswa kurang teliti dalam melakukan perhitungan padahal sudah memahami soal dengan baik.

Analisis ini sesuai dengan hasil yang diteliti oleh Ratna (2017) bahwa pada siswa terdapat hubungan dalam kemampuan pemecahan masalah dan self efficacy yang menunjukkan ketidak beranian siswa dalam bertanya sehingga mempengaruhi kemampuan pemecahan masalah siswa itu sendiri. Berdasarkan hasil analisis dari kemampuan pemahaman konsep dan pemecahan masalah matematis, yaitu persentase kesalahan ketiga indikator sangat rendah dikarenakan masih ada beberapa siswa yang tidak mampu dalam menyelesaikan soal sistem persamaan linear dua variable dalam bentuk soal kontektual, dapat dilihat persentase kesalahan ketiga indikator sangat rendah. Siswa sudah mampu dengan baik dalam memahami soal, menuliskan pernyataan yang diketahui dalam bentuk matematis dengan baik, konsep SPLDV yang benar, dan penyelesaian dengan tepat. 
Begitu juga hasil analisis dari kemampuan pemecahan masalah, siswa dalam mengerjakan soal SPLDV sangat baik. Dapat dilihat juga dari perolehan nilai yang mencapai rata - rata 90.71.

\section{PEMBAHASAN}

1. Kemampuan pemahaman konsep matematis siswa VIII SMP IT Dar Al-Ma'arif, dilihat dari indikator pemahaman konsep matematis sebagai berikut :

a. Indikator kemampuan siswa dalam menyatakan ulang sebuah konsep dan mengklasifikasikan objek sesuai dengan konsepnya, kesalahan dalam indikator ini tergolong sangat rendah yaitu sebesar 2,38\%. kesalahan ini meliputi kesalahan dalam mengklasifikasikannya.

b. Indikator kemampuan siswa dalam menyajikan konsep dalam berbagai bentuk representasi matematis, kesalahan dalam indikator ini tergolong sangat rendah juga yaitu sebesar 4,76\%. Kesalahan ini meliputi kesalahan siswa dalam merepresentasikan konsep SPLDV ke dalam bentuk matematis.

c. Indikator kemampuan siswa dalam menggunakan, memanfaatkan, dan memilih prosedur atau operasi tertentu dan mengaplikasikan konsep, kesalahan dalam indikator ini tergolong sangat rendah juga yaitu sebesar 1,19\%. Kesalahan ini meliputi kesalahan siswa dalam mengaplikasikan konsep SPLDV.

2. Kemampuan pemecahan masalah matematis siswa VIII SMP IT Dar Al-Ma'arif, dilihat dari indikator pemecahan masalah matematis sebagai berikut:

a. Indikator kemampuan siswa dalam memiilih dan menerapkan strategi untuk menyelesaikan masalah matematika dan atau di luar matematika, kesalahan dalam indikator ini tergolong sangat rendah juga yaitu sebesar 7,14\%. Kesalahan ini meliputi kesalahan siswa dalam memilih strategi untuk menyelesaikan masalah matematika.

b. Indikator kemampuan siswa dalam menjelaskan dan menginterpretasikan hasil, kesalahan dalam indikator ini tergolong sangat rendah juga yaitu sebesar 5,95\%. Kesalahan ini meliputi kesalahan siswa dalam menjelaskan dan mengemukakan hasil penyelesaian masalah matematika pada soal SPLDV.

\section{KESIMPULAN}

Analisis Kesalahan pemahaman konsep matematika yang dialami siswa kelas VIII SMP IT Dar Al-Ma'arif dilihat dari siswa dalam menyelesaikan soal SPLDV disebabkan oleh Kesalahan ini disebabkan karena siswa menganggap soal sulit dan kurang antusias untuk memahami soal, sebagian kecil siswa bingung untuk mengkomunikasikan pernyataan yang diketahui ke dalam model matematika sehingga siswa bingung menyelesaikan soal tersebut. Sedangkan pada analisis kemampuan pemecahan masalah matematis siswa cenderung melakukan kesalahan dalam perhitungan, sehingga penyelesaian menjadi tidak tepat. disebabkan siswa masih kurang teliti dalam melakukan perhitungan padahal sudah memahami soal dengan baik.

Dari data yang diperoleh terlihat bahwa kesalahan setiap indikator pemahaman konsep dan pemecahan masalah matematis siswa tergolong sangat rendah. Data ini diperoleh sesuai soal yang dikerjakan oleh siswa.

Dari hasil analisis data di atas juga diperoleh tinggginya kemampuan pemahaman konsep matematis siswa terkait dengan tingginya kemampuan pemecahan masalah matematis siswa, sehingga dapat disimpulkan adanya hubungan antara kedua kemampuan tersebut.

\section{DAFTAR PUSTAKA}

Aan Hendrayana. (2017). Pengaruh Pembelajaran Pendekatan Rigorous Mathematical Thinking (RMT) terhadap Pemahaman Konseptual Matematis Siswa SMP. Jurnal Riset Pendidikan Matematika, 4 (2), 186-199.

Anna Fauziah. (2010). Peningkatan Kemampuan Pemahaman dan Pemecahan Masalah Matematik Siswa SMP melalui Strategi React. Forum Kependidikan, 30 (1), 1-13 
Fadhila El Husna, Fitriani Dwina dan Dewi Murni. (2014). Penerapan Strategi REACT dalam Meningkatkan Kemamupan Pemahaman Konsep Matematika Siswa Kelas X SMAN 1 Batang Anai. Jurnal Pendidikan Matematika, 3 (1), Jurnal Pendidikan Matematika, 3 (2), 26-30

I Kt Agus Budi Artana, I Ny Wirya dan I Md Citra Wibawa. (2014). Pengaruh Strategi React terhadap Kemampuan Pemecahan Masalah Matematika Siswa Kelas IV SD 2 Paket Agung. e-journal MIMBAR PGSD Universitas Pendidikan Ganesha Jurusan PGSD, 2 (1), 1-11.

Kamarullah. (2017). Pendidikan Matematika di Sekolah Kita. Jurnal Al Khawarizmi. 1 (1), 21-32.

Nela Rizka, Hendra Syarifuddin dan Suherman. (2014). Pengaruh Penerapan Strategi Relating, Experiencing, Appliying, Cooperating, Transferring terhadap Kemampuan Pemahaman Konsep Matematika Siswa Kelas X SMAN 2 Payakumbuh. Jurnal Pendidikan Matematika, 3 (2), 44-48.

Ratna Widianti Utami dan Dhoriva Urwatul Wutsqa. (2017). Analisis Kemampuan Pemecahan Masalah Matematika dan Self-Efficacy Siswa SMP Negeri di Kabupaten Ciamis. Jurnal Riset Pendidikan Matematika, 4 (2), 166-175.

Rezi Ariawan dan Hayatun Nufus. (2017). Hubungan Kemampuan Pemecahan Masalah Matematis dengan Kemampuan Komunikasi Matematis Siswa. Jurnal THEOREMS (The Original Research of Mathematics). 1 (2), 82-91.

Rosliana H, Izwita dan Sumarno. Perbedaan Peningkatan Kemampuan Komunikasi Dan Koneksi Matematis Siswa Melalui Pembelajaran Kontekstual Dengan Kooperatif Tipe Stad Di Smp Alwashliyah 8 Medan. Jurnal Pendidikan Matematika PARADIKMA, 5 (2), 186-204.

Suraji dan Arnida Sari. (2017). Penerapan Model Kooperatif tipe Two Stay Two Stray (TSTS) dalam Upaya Meningkatkan Kemampuan Pemecahan Masalah Matematis Siswa SD. Suska Journal of Mathematics Education, 3 (2), 67-73.

Susanti. (2017). Meningkatkan Kemampuan Pemecahan Masalah Matematis dan Self Efficacy Siswa MTs melalui Pendekatan Pendidikan Matematika Realistik. Suska Journal of Mathematics Education, 3 (2), 92-101.

Umy Hasanatul Latifah dan Djamilah Bondan W. (2017). Pengembangan Bahan Ajar Statistika dan Peluang Berbasis Multiple Intelligences berorientasi pada Prestasi, Pemecahan Masalah dan Rasa Ingin Tahu. Jurnal Riset Pendidikan Matematika, 4 (2), 176-185. 